\title{
The origin of sea salt in snow on Arctic sea ice and in coastal regions
}

\author{
F. Domine ${ }^{1}$, R. Sparapani ${ }^{2}$, A. Ianniello ${ }^{2}$, and H. J. Beine ${ }^{2}$ \\ ${ }^{1}$ CNRS, Laboratoire de Glaciologie et Geophysique de l'Environnement, BP 96, 38402 Saint Martin d'Hères cedex, France \\ ${ }^{2}$ C.N.R.-IIA, Via Salaria Km 29,3 , I-00016 Monterotondo Scalo (Roma), Italy
}

Received: 19 May 2004 - Published in Atmos. Chem. Phys. Discuss.: 24 August 2004

Revised: 20 October 2004 - Accepted: 30 October 2004 - Published: 23 November 2004

\begin{abstract}
Snow, through its trace constituents, can have a major impact on lower tropospheric chemistry, as evidenced by ozone depletion events (ODEs) in oceanic polar areas. These ODEs are caused by the chemistry of bromine compounds that originate from sea salt bromide. Bromide may be supplied to the snow surface by upward migration from sea ice, by frost flowers being wind-blown to the snow surface, or by wind-transported aerosol generated by sea spray. We investigate here the relative importance of these processes by analyzing ions in snow near Alert and Ny-Ålesund (Canadian and European high Arctic) in winter and spring. Vertical ionic profiles in the snowpack on sea ice are measured to test upward migration of sea salt ions and to seek evidence for ion fractionation processes. Time series of the ionic composition of surface snow layers are investigated to quantify wind-transported ions. Upward migration of unfractionated sea salt to heights of at least $17 \mathrm{~cm}$ was observed in winter snow, leading to $\mathrm{Cl}^{-}$concentration of several hundred $\mu \mathrm{M}$. Upward migration thus has the potential to supply ions to surface snow layers. Time series show that wind can deposit aerosols to the top few $\mathrm{cm}$ of the snow, leading also to $\mathrm{Cl}^{-}$ concentrations of several hundred $\mu \mathrm{M}$, so that both diffusion from sea ice and wind transport can significantly contribute ions to snow. At Ny-Ålesund, sea salt transported by wind was unfractionated, implying that it comes from sea spray rather than frost flowers. Estimations based on our results suggest that the marine snowpack contains about 10 times more $\mathrm{Na}^{+}$than the frost flowers, so that both the marine snowpack and frost flowers need to be considered as sea salt sources. Our data suggest that ozone depletion chemistry can significantly enhance the $\mathrm{Br}^{-}$content of snow. We speculate that this can also take place in coastal regions and contribute to propagate ODEs inland. Finally, we stress the need to measure snow physical parameters such as permeability and specific surface area to understand quantitatively changes in snow chemistry.
\end{abstract}

Correspondence to: F. Domine

(florent@lgge.obs.ujf-grenoble.fr)

\section{Introduction}

Interactions between the snowpack and the atmosphere lead to important modifications of atmospheric composition (Domine and Shepson, 2002), and a most dramatic example is the complete destruction of ozone from the ground up to altitudes greater than $1000 \mathrm{~m}$, observed in the Arctic (Bottenheim et al., 2000) and the Antarctic (Tarasick and Bottenheim, 2002) in the spring, when the frozen sea and the ground are almost entirely snow-covered. It is now reasonably certain that brominated species, derived from sea salt bromide, are key species in the chemistry of this ozone destruction (Barrie et al., 1988; Fan and Jacob, 1992; Tang and McConnell, 1996).

However, many aspects of this chemistry are not fully understood and prevent the detailed modeling, let alone the prediction, of these ozone depletion events (ODEs) (Bottenheim et al., 2002a). Among these, the processes by which sea salt and bromide reach the snow surface to become available for activation into brominated compounds is unclear. Three major processes can be envisaged.

The first process involves frost flowers, that often form on the refrozen surface of open leads and have a salinity around $100 \mathrm{~g} / \mathrm{kg}$ (hereafter practical salinity units: psu) (Perovich and Richter-Menge, 1994). Frost flowers are thought to have a high specific surface area that would provide favorable sites for bromine activation (Rankin et al., 2002). Alternatively, they are fragile structures that can be readily windblown and redistributed to the snow surface, where they can constitute an available source of sea salt (Wolff et al., 2003). Precipitation of mirabilite $\left(\mathrm{Na}_{2} \mathrm{SO}_{4} \cdot 10 \mathrm{H}_{2} \mathrm{O}\right)$ from the brine at the surface of refrozen ice often accompanies frost flower formation (Rankin et al., 2002), with the result that sea salt coming from wind-blown frost flowers is depleted in sodium and sulphate. Because Antarctic sea salt aerosol is often depleted in sodium and sulphate, especially in winter when the extent of sea ice is largest (Wagenbach et al., 1998), it has been concluded that sea ice, by the formation of fragile frost flowers, was the main source of sea salt to

(C) 2004 Author(s). This work is licensed under a Creative Commons License. 


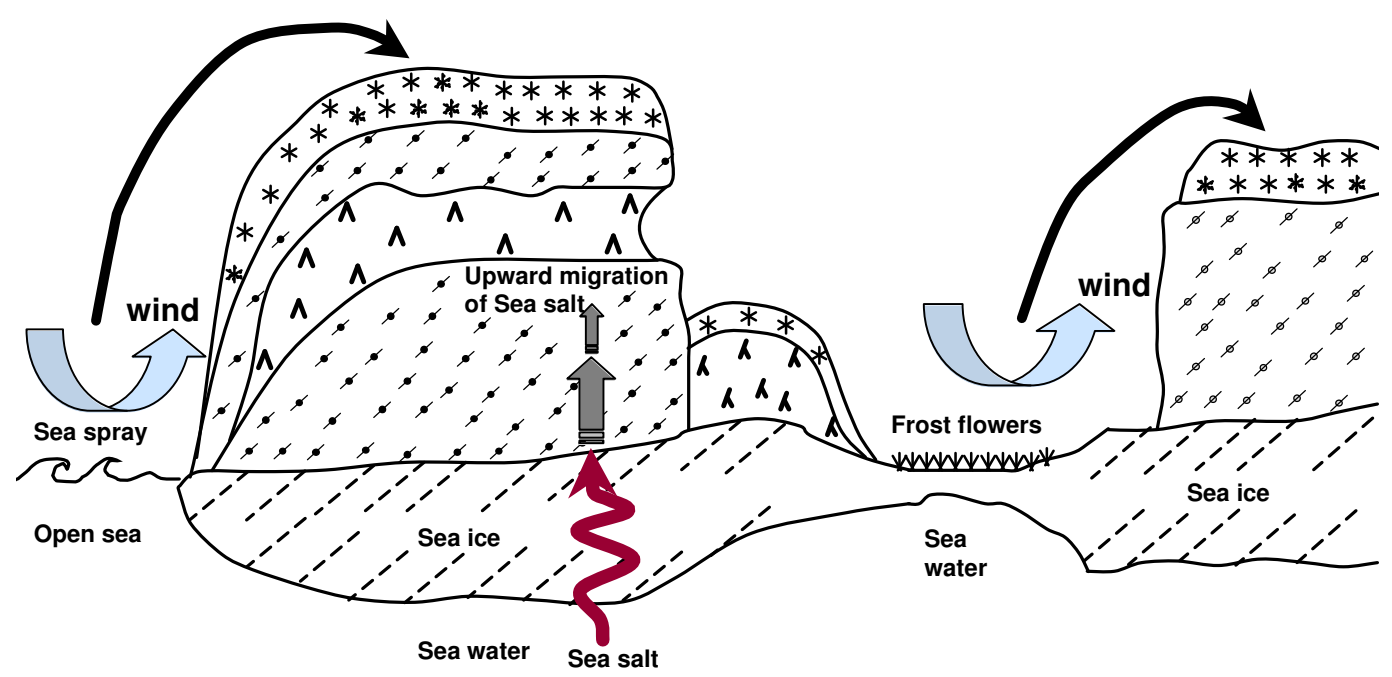

Fig. 1. Illustration of the main three processes suspected of supplying sea salt ions to marine snow: wind-transport of sea spray, upward migration from sea ice, and wind-blown frost flowers.

snow on the Antarctic continent and on surface marine snow (Wolff et al., 2003). Kaleschke et al. (2004) concluded from a modeling study that most ODEs could be correlated to the occurrence of frost flowers, which stresses the importance of these crystals. However, frost flowers provide intense point sources of sea salt to the atmosphere and snow and are easier to detect (for example from their strong radar backscatter signal) than more widespread and less intense processes that may also have a significant global impact, such as the following process.

The second process is the upward migration of a sea salt enriched brine from the sea ice to the snowpack. Brines are often present at the sea ice-snow interface and can travel up the snow by capillary forces (Perovich and Richter-Menge, 1994). The wettability of snow crystal surfaces by the brine is then the driving force for this process. Numerous studies in Antarctica (Eicken et al., 1994; Massom et al., 2002) have shown that salinities up to 5 psu could often be found in snow at a height of $20 \mathrm{~cm}$ above the sea ice. More limited studies in the Arctic have also shown that a slush layer was present at the surface of Arctic ice (Garrity, 1992) from which the capillary motion of a brine can be inferred. Direct salinity measurements (Eicken et al., 2002) have also shown that high salinities could be found in snow on sea ice. However, these measurements were done in the summer, when the warmer temperatures favor the presence of a liquid phase, while ozone depletion episodes mostly take place around early spring. It is thus not clear whether surface snow, that is more susceptible to interact with the atmosphere, can be directly affected by sea salt migrating up from the sea ice in the spring.

The third process is the transport of sea salt aerosol generated by sea spray (Buat-Ménard et al., 1974) to snow-covered surfaces. Rankin et al. (2000) concluded that the open sea was not as efficient a source of sea salt aerosol as frost flowers, for transport to the Antarctic coast. However, in places such as Svalbard, where the open sea is never far because of the presence of the Gulf stream, and where ODEs have been observed (Solberg et al., 1996), this process cannot be ruled out and deserves investigation.

These three processes, that can bring bromide from sea salt into the surface layers of the marine snowpack, are illustrated in Fig. 1. Understanding and modeling the flux of brominated compounds to the atmosphere through bromide activation requires, among many other aspects, the determination of which of these three processes is predominant. The importance of each process may also evolve with climate change, and determining their current state is a first step towards predicting the future availability of bromide for activation in surface snow.

To help shed some light on this question, we took advantage of three expeditions to the Arctic to sample snow on the sea ice, where the direct influence of the underlying ocean would be detectable, and on land near the coast, where the influence of marine air masses would be felt, but not that of migration from sea ice. These expeditions were the winter and spring intensive campaigns of Alert 2000 (Bottenheim et al., 2002b) and the spring intensive of the NICE campaign in Ny-Ålesund, Spitsbergen, in April/May 2001 (Beine et al., 2003).

Our approach was to analyze mineral ions in snow by ion chromatography. Ion speciation yields useful data, compared to salinity measurements. Indeed, fractionation processes that can take place then become detectable, and this helps determine which process took place. For example, sodium and sulphate depletion due to mirabilite precipitation 
Table 1. Operating conditions of the IC analyses during all campaigns.

\begin{tabular}{lll}
\hline & IC DX 100 cation analysis & IC DX 120 anion analysis \\
\hline Column & CS12A $(4 \times 250 \mathrm{~mm})$ & AS12A $(4 \times 200 \mathrm{~mm})$ \\
Pre-column & CG12A $(4 \times 50 \mathrm{~mm})$ & AG12A $(4 \times 50 \mathrm{~mm})$ \\
Suppressor & CSRS-II $(4 \mathrm{~mm})$ & ASRS-II $(4 \mathrm{~mm})$ \\
Operative Flow Rate & $1 \mathrm{ml} / \mathrm{min}$ & $1.5 \mathrm{ml} / \mathrm{min}$ \\
Loop & $150 \mu \mathrm{l}$ & $300 \mu \mathrm{l}$ \\
Elution procedure & Isocratic & isocratic \\
Dionex Eluent & Methanesulphonic acid, $\mathrm{MSA}_{20 \mathrm{mM}}$ & $\mathrm{Buffer}$ solution of $\mathrm{Na}_{2} \mathrm{CO}_{3} 2.1 \mathrm{mM}, \mathrm{NaHCO}_{3} 0.8 \mathrm{mM}_{4}$ \\
Analyte species & $\mathrm{Na}^{+}, \mathrm{K}^{+}, \mathrm{Ca}^{2+}, \mathrm{Mg}^{2+}, \mathrm{NH}_{4}^{+}$ & $\mathrm{SO}_{4}^{2-}, \mathrm{NO}_{3}^{-}, \mathrm{Cl}^{-}, \mathrm{NO}_{2}^{-}, \mathrm{Br}^{-}$ \\
Detector & Conductivity cell & $\mathrm{Conductivity} \mathrm{cell}^{-}$ \\
\hline
\end{tabular}

are expected if snow is affected by frost flowers deposited by wind (Rankin et al., 2002).

We present here vertical profiles and time series of ion compositions in several Arctic locations. Our initial objective in these sampling campaigns was not to answer the title question of this paper, and the first samplings were thus not perfectly targeted. Subsequent samplings became more adequately focused. Although the present data do not fully answer our question, we feel that they do bring a useful contribution to our understanding of the mechanism of transfer of sea salt and bromide to Arctic snow.

\section{Experimental methods}

\subsection{Sites}

Around Alert, (North coast of Ellesmere island, Canadian high Arctic) the sampling site on land was within $400 \mathrm{~m}$ of the FTX building $\left(82^{\circ} 27.28^{\prime} \mathrm{N}, 62^{\circ} 29.69^{\prime} \mathrm{W}\right.$, Domine et al., 2002), about $5.4 \mathrm{~km}$ from the coast. On the sea ice, the winter sampling site was on Joliffe bay $\left(82^{\circ} 31.07^{\prime} \mathrm{N}, 62^{\circ} 42.05^{\prime} \mathrm{W}\right)$ and the spring sampling site was at $82^{\circ} 31.74^{\prime} \mathrm{N}, 62^{\circ} 44.39^{\prime} \mathrm{W}$, near Williams island. Sampling was also done on the Northern Arctic ocean on 25 April 2000 , at $84^{\circ} 56^{\prime} \mathrm{N}, 67^{\circ} 28^{\prime} \mathrm{W}$.

Around Ny-Ålesund (Svalbard archipelago, Spitsbergen island, European high Arctic), sampling was done near the $\mathrm{Ny}$-Ålesund village $\left(78^{\circ} 55.45 \mathrm{~N}, 11^{\circ} 55.67 \mathrm{E}\right)$ by the Amundsen mast, about $30 \mathrm{~m}$ from the shoreline. Sampling on the sea ice was in one of the rare locations where sea ice

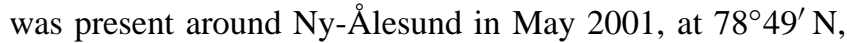
$11^{\circ} 40^{\prime} \mathrm{E}$.

\subsection{Snow sampling}

Snow was sampled in a manner essentially similar to that described by Domine et al. (2002) for physical measurements. Polyethylene gloves were used to avoid contamination, and snow was sampled into polyethylene sampling vials. For
Table 2. Laboratory precision and detection limits during all campaigns.

\begin{tabular}{ccc}
\hline Measured species by IC & Precision $^{1}[\%]$ & $3 \sigma$ L.O.D. $[\mu \mathrm{M}]$ \\
\hline $\mathrm{Cl}^{-}$ & 3.33 & 0.05 \\
$\mathrm{NO}_{2}^{-}$ & 3.29 & 0.013 \\
$\mathrm{Br}^{-}$ & 1.40 & 0.01 \\
$\mathrm{NO}_{3}^{-}$ & 1.36 & 0.01 \\
$\mathrm{SO}_{4}^{2-}$ & 2.18 & 0.02 \\
$\mathrm{Na}^{+}$ & 2.99 & 0.04 \\
$\mathrm{NH}_{4}^{+}$ & 3.63 & 0.02 \\
$\mathrm{~K}^{+}$ & 2.29 & 0.01 \\
$\mathrm{Mg}^{2+}$ & 2.46 & 0.08 \\
$\mathrm{Ca}^{2+}$ & 1.42 & 0.25 \\
\hline
\end{tabular}

${ }^{1}$ The laboratory precision is estimated on the basis of repeated analyses carried out at a concentration level of $100 \mathrm{ng} / \mathrm{ml}$ typical of samples collected in polar sites.

each snow layer, triplicate samples were taken for anions and another set of triplicates was taken for cations. Samples were usually melted and analyzed on site by ion chromatography within $12 \mathrm{~h}$ of sampling, and in a few cases were stored frozen for up to $48 \mathrm{~h}$ before analysis.

\subsection{Ion chromatography analyses}

Melted snow was analyzed by ion chromatography (Dionex IC mod. DX120 and DX100) using Dionex AS12 and CS12 columns for anions and cations, respectively, as detailed in Table 1. Detection was by conductimetry coupled with post-column suppression of eluent ions. The use of selfregenerating suppressors that enhance analyte conductivity while suppressing eluent conductivity allowed parts-perbillion (ppb) detection limits for anions and cations without preconcentration.

To optimize detection limits and to ensure quality data, special care was taken in the field and in the laboratory to the 

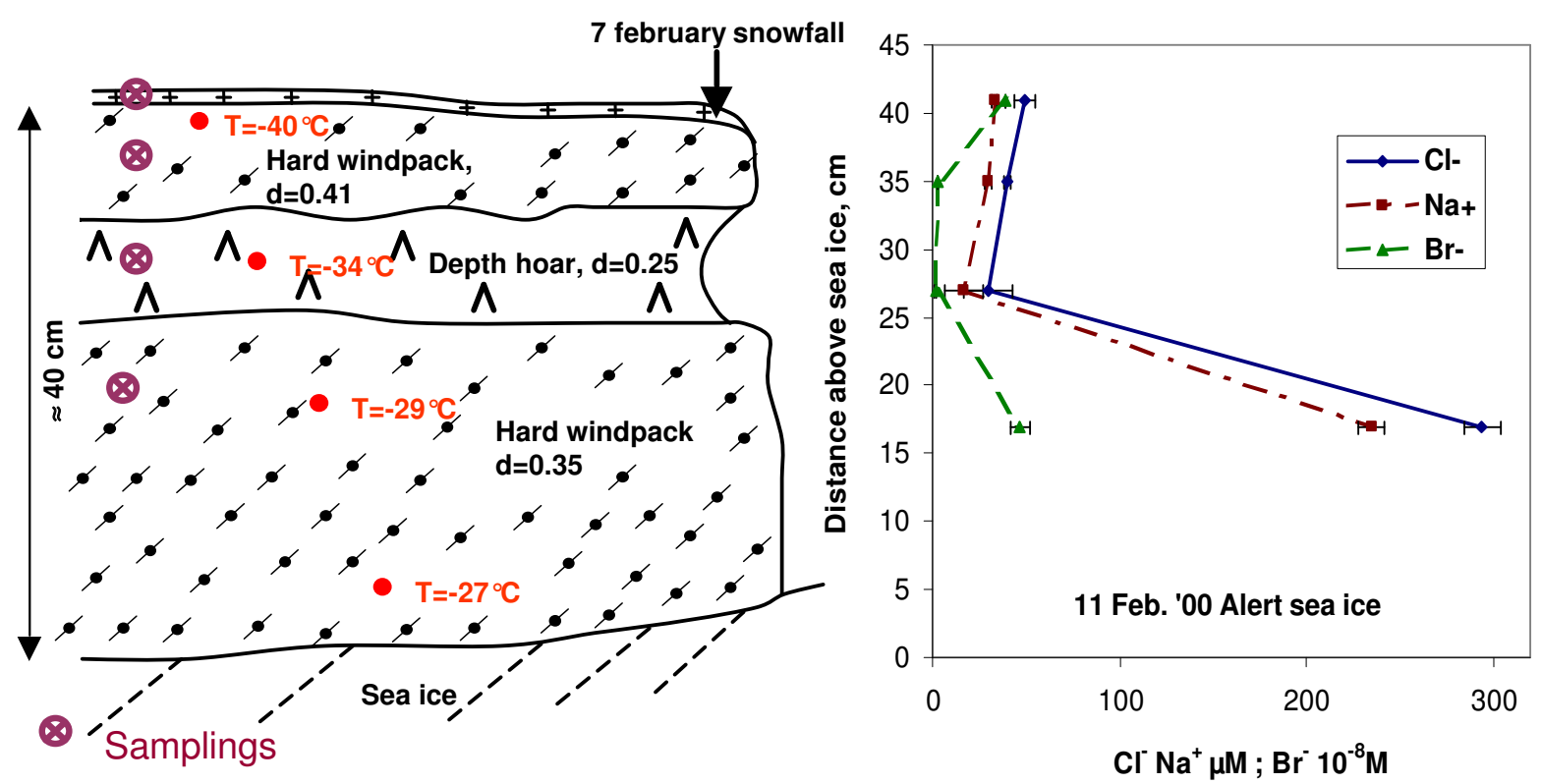

Fig. 2. Stratigraphy and concentrations of $\mathrm{Cl}^{-}, \mathrm{Na}^{+}$and $\mathrm{Br}^{-}$in a snow bank on sea ice near Alert, on 11 February 2000 . Density (d) and temperature (T) values of the snow are indicated. Symbols for snow crystals are those recommended by Colbeck et al. (1990).

quality control/assurance procedures (Allegrini et al., 1999; Perrino et al., 2001). The lower detection limits (L.O.D.) of the analytical technique (Table 2) were calculated as the analyte signal which is three times the standard deviation $(3 \sigma)$ of a near-zero concentration measurement. The precision and accuracy of ion chromatography measurements were determined from the standard deviation and mean of repeated analyses of the laboratory standard. Typically, a multipoint calibration (seven standards in the range 5-1000 ppb) was used. The correlation coefficient from the regression equation of the average values was always greater than 0.999 . The IC response was linear up to $20 \mu \mathrm{M}$ for each chemical species analyzed, and dilutions were performed for more concentrated samples. For chromatographic analyses, control samples, consisting of calibration solutions of anions $\left(\mathrm{Cl}^{-}, \mathrm{Br}^{-}, \mathrm{NO}_{3}^{-}, \mathrm{NO}_{2}^{-}, \mathrm{SO}_{4}^{2-}\right)$ and cations $\left(\mathrm{Na}^{+}, \mathrm{NH}_{4}^{+}, \mathrm{K}^{+}\right.$, $\left.\mathrm{Mg}^{2+}, \mathrm{Ca}^{2+}\right)$, were analyzed every twenty samples in order to re-calibrate the ion chromatograph. Calibration solutions were prepared every two weeks from $1000 \mathrm{ppm}$ standard solutions of salts (MERCK).

\section{Results and discussion}

\subsection{Vertical profiles on pack ice}

The snow pack was studied in Joliffe Bay, near Alert, on 11 and 17 February 2000. The ice is essentially permanent there, and the probability that our sampling was on multiyear ice is then high. The snow stratigraphy was very variable, as detailed by Domine et al. (2002), with snow depth varying between 0 and $50 \mathrm{~cm}$. The aspect of the snow bank that was sampled is shown in Fig. 2, along with sampling levels. The snow temperature near the surface was $-40^{\circ} \mathrm{C}$, increasing to $-27^{\circ} \mathrm{C} 5 \mathrm{~cm}$ above the sea ice and no liquid water could be detected. The $\mathrm{Na}^{+}, \mathrm{Cl}^{-}$, and $\mathrm{Br}^{-}$profiles are also shown in Fig. 2. The maximum concentrations, with $295 \mu \mathrm{M}$ of $\mathrm{Cl}^{-}$ are found in the windpack closest to the sea ice, and the minimum concentrations $\left(30 \mu \mathrm{M}\right.$ of $\left.\mathrm{Cl}^{-}\right)$are found in the depth hoar. $\mathrm{Cl}^{-} / \mathrm{Na}^{+}$molar ratios vary from 1.25 (lowest sampled layer) to 1.79 (depth hoar), i.e. somewhat higher than the sea salt value of 1.165 (Holland, 1978). This difference is not significant for the lowest layer sampled. $\mathrm{Cl}^{-} / \mathrm{Br}^{-}$values are 631 in the lower windpack, essentially identical to the sea water value of 647 (Holland, 1978), while it is 126 for the uppermost layer, i.e. enriched in $\mathrm{Br}^{-}$by a factor of 5 relative to sea water. This ratio is around 1700 for both middle layers, but the $\mathrm{Br}^{-}$value is close to the detection limit, implying a large uncertainty. It nevertheless appears likely that these layers are depleted in $\mathrm{Br}^{-}$relative to sea salt. Subsequent samplings at the same levels on 17 February yielded similar results. Interestingly, the lowest layer sampled had ratios of $\mathrm{Cl}^{-}, \mathrm{Br}^{-}, \mathrm{Mg}^{2+}$, and $\mathrm{K}^{+}$to $\mathrm{Na}^{+}$within $10 \%$ of those of sea water. $\mathrm{Ca}^{2+} / \mathrm{Na}^{+}$was 10 times the ocean value, but this can be explained by soil dust (Toom Sauntry and Barrie, 2002), whose ubiquitous presence in the lowermost snow layers gives the snow a darker color. Furthermore, the highest ionic concentrations were also found in this layer, and it appears reasonable to suggest that unfractionated sea salt was present $17 \mathrm{~cm}$ from the ice $/$ snow interface, and that it reached this snow by migration from the sea ice. Unfortunately, no 

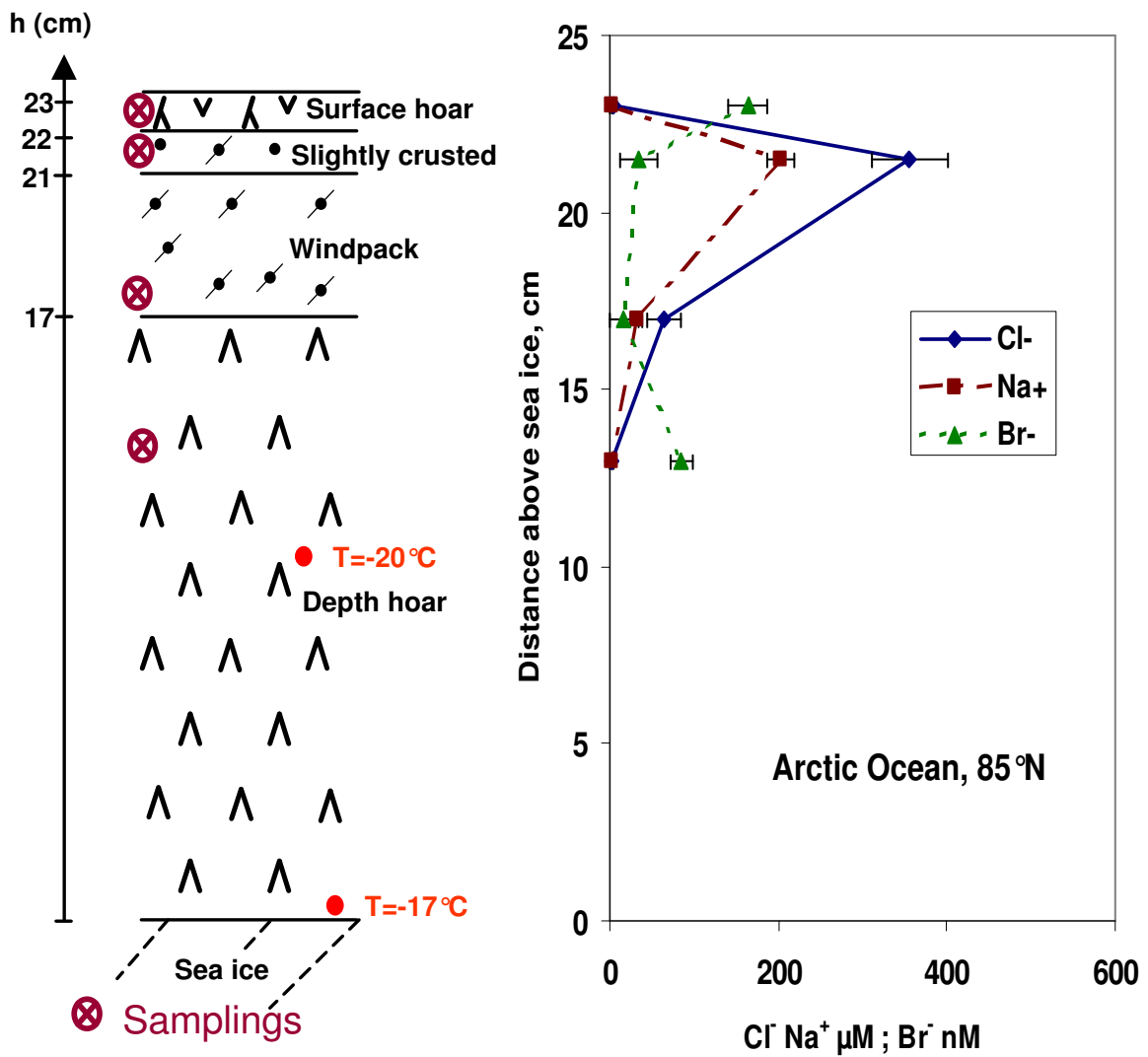

Fig. 3. Stratigraphy and concentrations of $\mathrm{Cl}^{-}, \mathrm{Na}^{+}$and $\mathrm{Br}^{-}$in a snow bank on the Northern Arctic $\mathrm{Ocean}\left(84^{\circ} 56^{\prime} \mathrm{N}, 67^{\circ} 28^{\prime} \mathrm{W}\right)$ on 25 April 2000.

detailed sampling was done in the vicinity of the sea ice to confirm the presence of a gradient and to evidence higher concentrations near the ice surface.

Migration from the sea ice may not explain all the compositions observed. $\left[\mathrm{Cl}^{-}\right]$in the uppermost layer is $49.8 \mu \mathrm{M}$, while that of the depth hoar is $30.1 \mu \mathrm{M}$. This may seem to rule out migration from the base of the snowpack. However, if migration of ions is by capillary forces and therefore takes place on the surface of snow crystals, it is possible that the ionic concentrations are proportional to the specific surface area (SSA) of the snow. Domine et al. (2002) mention that the depth hoar, the top windpack, and the recent surface snow had SSAs of 200, 240, and $680 \mathrm{~cm}^{2} / \mathrm{g}$, respectively. The higher SSA of the higher layers imply that upward migration may have produced higher concentrations in these layers than in lower ones. However, an examination of the ionic ratios shows that the snow composition is different from that of sea salt. For example, in the top snow layer, $\mathrm{Mg}^{2+} / \mathrm{Na}^{+}$ and $\mathrm{K}^{+} / \mathrm{Na}^{+}$are 2.1 and 1.7 times the sea salt values. We then conclude that, even if upward migration reached surface snow, wet or dry deposition made significant contributions to the ionic content of the surface snow layers.
Data obtained on the Arctic Ocean site $\left(84^{\circ} 56^{\prime} \mathrm{N}\right.$, $67^{\circ} 28^{\prime} \mathrm{W}$ ) on 25 April 2000 tend to confirm this conclusion. The sampling site was in the vicinity of a recently refrozen lead, on an ice plate surrounded by pressure ridges. Judging from the extensive depth hoar development, the ice must have formed in the previous fall, and may even have been multiyear ice. The snow stratigraphy and chemistry are shown in Fig. 3. Large concentrations of sodium $(202 \mu \mathrm{M})$ and chloride $(356 \mu \mathrm{M})$ were seen near the surface, while much lower values $(1.4$ and $2.7 \mu \mathrm{M})$ were observed in the lowermost layer sampled, $13 \mathrm{~cm}$ above the ice. This clearly rules out upward capillary migration to explain the high near-surface concentrations. Ionic ratios are also very different from sea water values. $\mathrm{Cl}^{-} / \mathrm{Na}^{+}$values in the 4 layers sampled are, from top to bottom, 2.75, 1.76, 2.06, 1.96, all much higher than the 1.165 ocean value. The $\mathrm{Cl}^{-} / \mathrm{Br}^{-}$ratios are 25 and 32 in the top and bottom layers, much lower than the 647 ocean value, indicating bromide enrichment by a factor over 20. On the contrary, both middle layers are very depleted, with $\mathrm{Cl}^{-} / \mathrm{Br}^{-}$ratios of 11000 and 3000, again with a large uncertainty. $\mathrm{Mg}^{2+} / \mathrm{Na}^{+}$and $\mathrm{K}^{+} / \mathrm{Na}^{+}$ratios are also greater than in sea water, by factors up to 5. This vertical profile thus clearly indicates that, although sea salt has to be invoked 

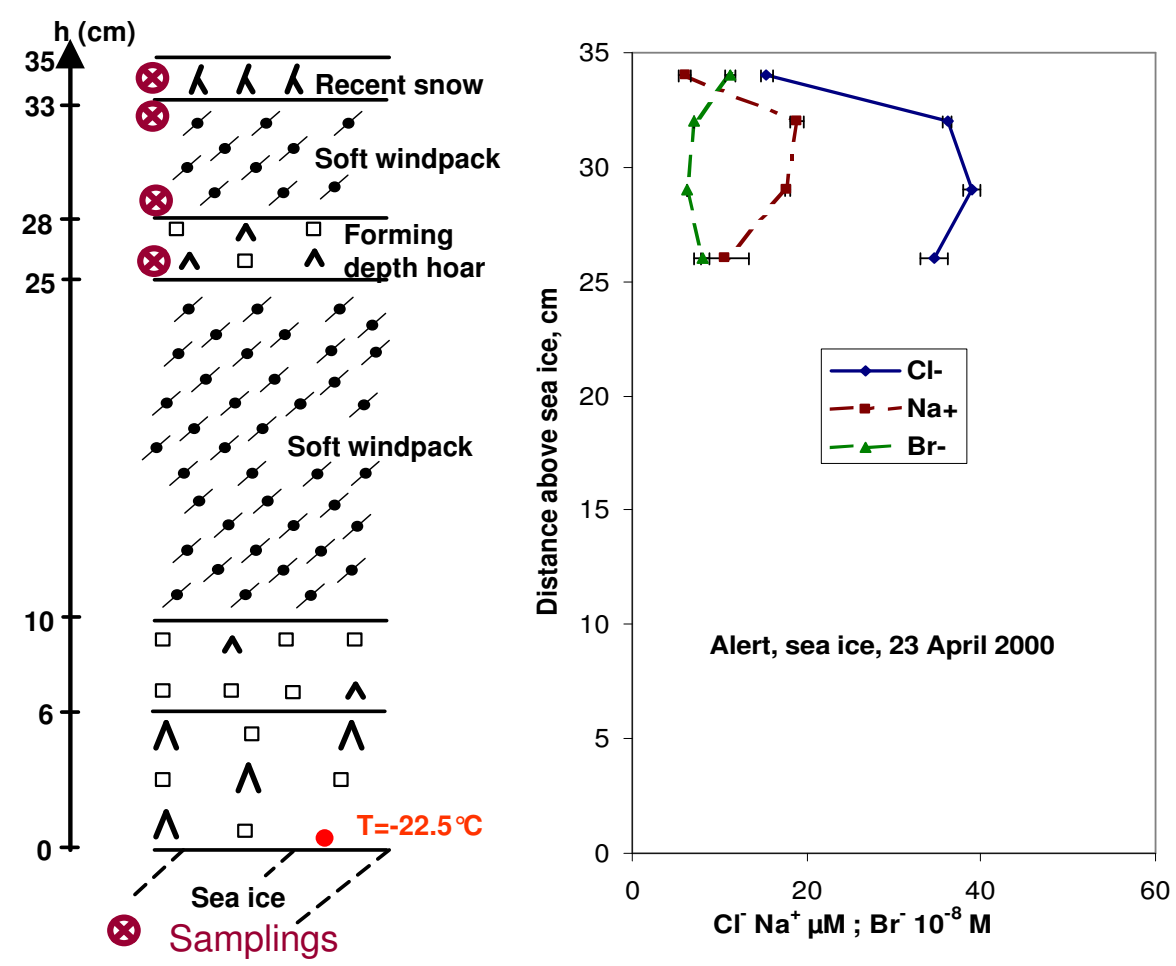

Fig. 4. Stratigraphy and concentrations of $\mathrm{Cl}^{-}, \mathrm{Na}^{+}$and $\mathrm{Br}^{-}$in a snow bank on sea ice near Alert, on 23 April 2000.

to explain the high sodium and chloride concentrations observed it clearly did not come directly upwards from the sea ice. The significant enrichment or depletion of all layers in $\mathrm{Br}^{-}$implies that the ions did not come directly from frost flower formation, as Rankin et al. (2002) have reported that in Antarctica, this ratio was similar to that of sea water. Depletion may be explained by $\mathrm{Br}^{-}$activation during ODEs, while enrichment may be due to the deposition of $\mathrm{HBr}$ produced by ODEs, in agreement with the suggestions of Simpson et al. (2004) $)^{1}$ who studied $\mathrm{Cl}^{-} / \mathrm{Br}^{-}$ratios in northern Alaska. The high $\mathrm{Mg}^{2+} / \mathrm{Na}^{+}$and $\mathrm{K}^{+} / \mathrm{Na}^{+}$ratios can be interpreted as a contribution from other sources, such as soil dust (as confirmed by high $\mathrm{Ca}^{2+}$ values) and anthropogenic emissions (as confirmed by high sulphate values).

These first two examples show that both upward migration and deposition from the atmosphere can lead to snow of salinity $0.02 \mathrm{psu}\left(\mathrm{Na}^{+}\right.$content around $\left.200 \mu \mathrm{M}\right)$, about $20 \mathrm{~cm}$ above the ice surface. However, snow compositions in both these cases are very different, and this makes it possible to conclude that upward migration took place near Alert, while wind deposition took place on the northern Arctic ocean.

A further example of sea salt ions brought by wet or dry deposition comes from a study of the snowpack on sea ice

\footnotetext{
${ }^{1}$ Simpson, W. R., Alvarez-Aviles, L., Douglas, T. A., Sturm, M., and Domine, F.: Halogens in the coastal snowpack near Barrow, Alaska: Evidence for active bromine air-snow chemistry during springtime, Geophys. Res. Lett., submitted, 2004.
}

near Alert on 23 April 2000 (Fig. 4). Again, only the top layers were analyzed. $\mathrm{Cl}^{-}$and $\mathrm{Na}^{+}$concentrations are fairly high, showing that sea salt contributed to snow chemistry. The shapes of the vertical profiles do not appear to be caused by upward transport, although windpacks usually have SSAs greater than depth hoar (Legagneux et al., 2002) and the process cannot be ruled out from the profiles only. Ionic ratios are different from those of sea salt: $\mathrm{Cl}^{-} / \mathrm{Na}^{+}$values in the 4 layers sampled are, from top to bottom, 2.55, 1.92, 2.20, 3.28. $\mathrm{Mg}^{2+} / \mathrm{Na}^{+}$and $\mathrm{K}^{+} / \mathrm{Na}^{+}$ratios are 3 to 5 times higher than in ocean water, again indicating multiple sources. Interestingly, the $\mathrm{Cl}^{-} / \mathrm{Br}^{-}$ratio is less different from the ocean values than in the preceding case. The top layer has a value of 137 , i.e. enriched by a factor of 5 relative to the ocean, but the other 3 layers have values of 515, 610 and 432, i.e. barely significantly different from the ocean values.

The importance of upward motion of salt from the sea ice was tested in the spring near $\mathrm{Ny}$-Ålesund. Figure 5 shows the stratigraphy and the $\mathrm{Cl}^{-}$profile of the snow pack on sea ice on 6 May 2001. Judging from the thin snowpack, the sea ice had formed recently, probably in late April. West Spitsbergen gets little sea ice, as it is under Gulf Stream influence. Moreover, 2001 was an anomalous year, in that the Fjord at Ny-Ålesund was only frozen for a few weeks in April. The snow temperature was fairly high, around $-5^{\circ} \mathrm{C}$, while the air temperature on this totally overcast day was $-5.4^{\circ} \mathrm{C}, 1.5 \mathrm{~m}$ above the surface. Significant amounts of 


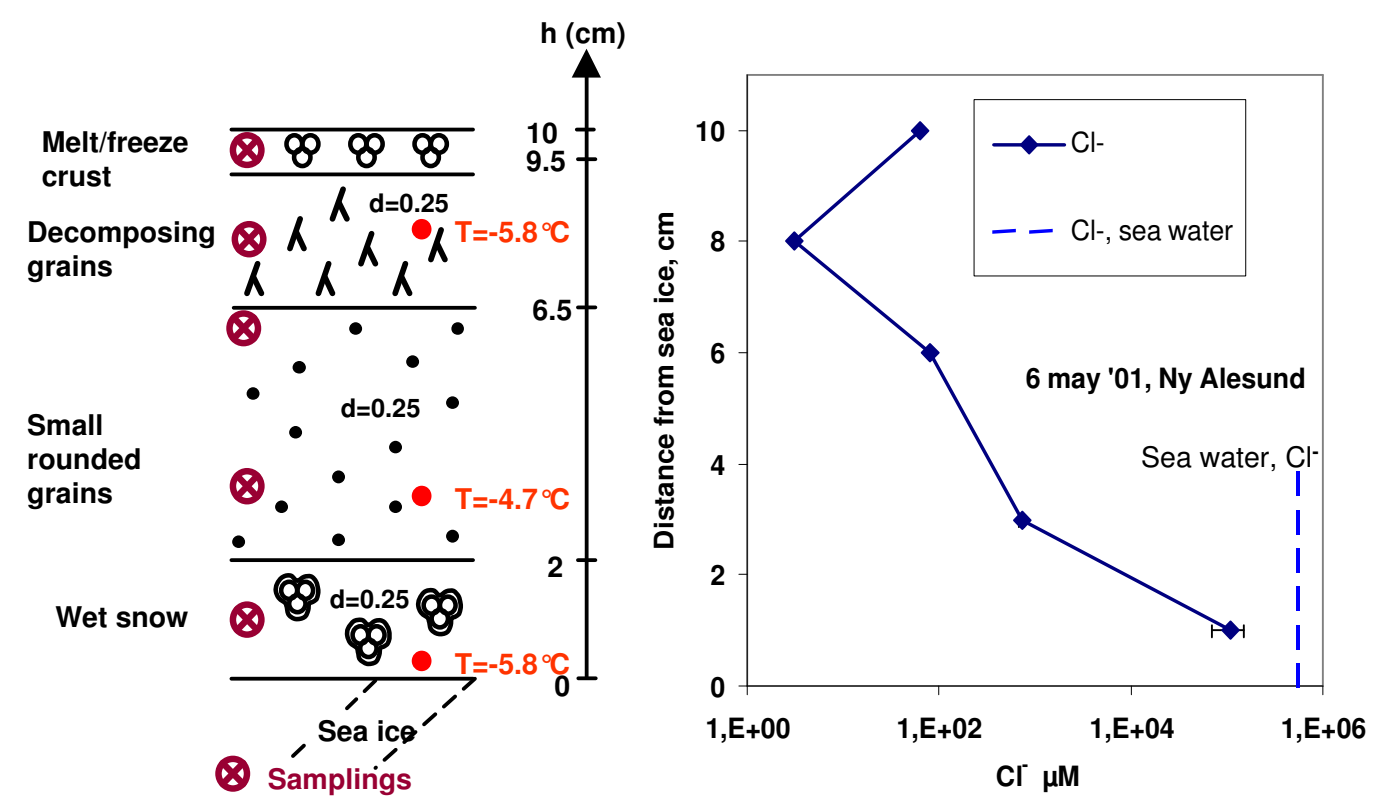

Fig. 5. Stratigraphy and concentrations of $\mathrm{Cl}^{-}$on sea ice near Ny-Ålesund, on 6 May 2001. Density (d) and temperature (T) values of the snow are indicated. Note that a log scale had to be used to show very large $\mathrm{Cl}^{-}$concentrations.

liquid water were observed in the bottom layer, $2 \mathrm{~cm}$ thick. Figure 5 shows that huge ionic concentrations exist in the lowest layer: this snow has a salinity of about 5 psu. It did not appear to be water-saturated, and this is confirmed by its low density of 0.25 . According to Colbeck (1982), this implies that the liquid water content was less than $14 \%$, and the liquid was then rather a brine with a $\mathrm{Cl}^{-}$content of at least $28 \mathrm{~g} / \mathrm{L}$. Unfortunately, an error in sample handling during the dilution procedure prevented the accurate quantification of all ions, and the values for this layer, are then lower limits. The measured $\mathrm{Cl}^{-} / \mathrm{Na}^{+}$ratio of 8.4 appears unrealistic and illustrates the problem encountered.

The $\mathrm{Cl}^{-}$profile of Fig. 5 clearly suggests that upward migration took place to a height of about $6 \mathrm{~cm}$. At that level, the composition of the snow appears consistent with migration of sea salt, and additional atmospheric input of $\mathrm{SO}_{4}^{2-}$ and $\mathrm{Ca}^{++}$. The $\mathrm{Cl}^{-} / \mathrm{Br}^{-}$ratio is half that of sea water, and this may be due to atmospheric input of $\mathrm{Br}^{-}$. The second layer from the top has very low ionic concentrations, and although ion ratios are close to those of sea water, we suggest that its composition is due to the atmospheric scavenging of mostly sea salt aerosol produced by sea spray. Finally, the $\mathrm{Cl}^{-}$concentration from the top layer, $62 \mu \mathrm{M}$, cannot be due to transport from the ice at all, considering the low concentration of the underlying layer.

Two conclusions can be derived from this vertical profile. First, upward transport of sea salt in the presence of a brine is clearly evidenced. This has already been concluded from snow salinity studies (Eicken et al., 1994; Massom et al., 2001). However, the interesting observation is that, even at the warm temperatures observed, upward capillary motion leads to high sea salt concentrations only up to 6 to $7 \mathrm{~cm}$, over a time scale that we estimate as a month at the most. Even in this thin $10 \mathrm{~cm}$ snowpack, the basal brine does not affect the top snow layer, at least over a time scale of about a month.

To sum up this section, 2 of these 4 profiles indicate that upward capillary motion does take place up to a certain height in the snowpack. In the other 2 cases, this conclusion is not reached simply because the relevant measurements were not made, and the existence of this physical process cannot be ruled out. However, in all 4 cases we can safely say that the composition of the uppermost snow layer was not significantly affected by upward capillary motion. The chemical composition of these top layers indicates several contributing sources, and we may have detected the effect of ozone depletion chemistry on snow composition, as this process may explain high $\mathrm{Br}^{-}$concentrations. Sea salt deposited from the atmosphere was clearly a contributor to the chemistry of the top snow layer. We cannot determine whether this "atmospheric" sea salt was supplied by frost flowers, as sulphate can have multiple sources, and the $\mathrm{SO}_{4}^{2-} / \mathrm{Na}^{+}$ratio cannot be used for that purpose. In the case of the Spitsbergen profile, $\mathrm{Cl}^{-}$depletion, possibly due to fractionation of atmospheric sea salt by sulphate (Legrand and Delmas, 1988) present in high concentrations, is visible in the top layer. In addition to these vertical profiles, time series of the chemistry of a given snow layer provide valuable insights into the processes responsible for snow composition. 

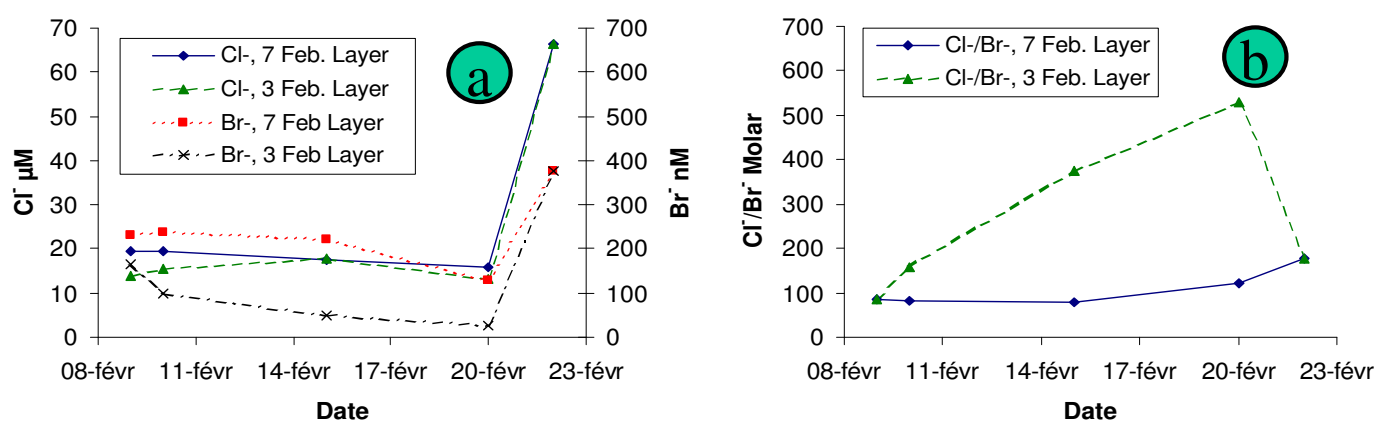

Fig. 6. (a) Time series of the $\mathrm{Cl}^{-}$and $\mathrm{Br}^{-}$concentrations of two snow layer on land, near Alert, in February 2000. Both snow layers were mixed together by a wind storm on 22 February, and were then sampled together. (b) Time series of the $\mathrm{Cl}^{-} / \mathrm{Br}^{-}$ratio of these same layers.

\subsection{Time series}

\subsubsection{3 and 7 February layers, Alert}

The chemistry of the snowfalls of 3 and 7 February 2000 (Domine et al., 2002) was monitored on land at Alert, near the FTX building. The evolutions of the $\mathrm{Cl}^{-}$and $\mathrm{Br}^{-}$concentrations are shown in Fig. 6a. As detailed in Domine et al. (2002) both layers were deposited on a hard wind-packed layer. The 3 February layer fell under windy conditions, accumulated in wind-sheltered spots such as the lee of sastrugi and was discontinuous. The 7 February layer fell under calm conditions and was homogeneous. Its composition indicates contributions from sea salt, long range transport of $\mathrm{SO}_{4}^{2-}$ and other ions, and a local source of several ions, essentially $\mathrm{Ca}^{2+}$ (Toom-Sauntry and Barrie, 2002). The $\mathrm{Cl}^{-}$concentrations showed little variations until 22 February. The slow decrease of $\mathrm{Cl}^{-}$in the 7 February layer is probably due to the dilution of this layer by surface hoar that formed continuously (Domine et al., 2002) but in insufficient amounts to be sampled separately. To try to determine the chemistry of surface hoar, hoar frost that was growing on antenna guy wires was sampled, and showed a $\mathrm{Cl}^{-}$content of $11.9 \mu \mathrm{M}$ on 16 February and of $13.3 \mu \mathrm{M}$ on 20 February, confirming the dilution suggestion. Until $20 \mathrm{February} \mathrm{Cl}^{-}$in the 3 February layer shows slight variations without a clear trend, ascribed, as in the case of its physical properties, to the spatially variable wind action during deposition (Domine et al., 2002). $\mathrm{Br}^{-}$decreases slightly in the 7 February layer, while its decrease is dramatic in the 3 February layer. A possible interpretation is that $\mathrm{Br}^{-}$is depleted by dark reactions that activate bromide into $\mathrm{Br}_{2}$ and $\mathrm{BrCl}$, as detected by Foster et al. (2001) with an instrument located near our sampling site. The decrease is less in the 7 February layer because $\mathrm{Br}^{-}$can be dry-deposited and because surface hoar contains $110 \mathrm{nM}$ of $\mathrm{Br}^{-}$, as suggested by hoar frost analyses.

As shown in Fig. $6 \mathrm{~b}$ the $\mathrm{Cl}^{-} / \mathrm{Br}^{-}$ratio is fairly stable around 100 in the 7 February layer until 20 February showing that $\mathrm{Br}^{-}$is enriched relative to sea salt by a factor of 5 to 8. Regarding the 3 February layer, the ratio on 9 February is similar to that of the upper layer, but then rises to 450 on 20 February.

On 22 February, a wind storm took place, with wind speeds measured at the nearby GAW laboratory that averaged $4 \mathrm{~m} / \mathrm{s}$ over about $8 \mathrm{~h}$, and with a maximum of $7 \mathrm{~m} / \mathrm{s}$. This mixed both layers and accumulated them in windsheltered spots, with the probable addition of a few loose crystals from the windpack. Both $\mathrm{Cl}^{-}$and $\mathrm{Br}^{-}$concentrations increased dramatically. Ianniello et al. (2002) analyzed aerosols and gases at Alert between 9 and 21 February 2000, with a $48 \mathrm{~h}$ time resolution. They report mean $\mathrm{HCl}$ and $\mathrm{HBr}$ atmospheric concentrations of 11.3 and $16.7 \mathrm{ng} . \mathrm{m}^{-3}$, while $\mathrm{Cl}^{-}$and $\mathrm{Br}^{-}$concentration from aerosols were 73.9 and $5.2 \mathrm{ng} \cdot \mathrm{m}^{-3}$. However, these values show much scatter with time, and to estimate a value for 22 February, we prefer to consider the value measured for the period from 19 to 21 February, which are undetectable for $\mathrm{HCl}, 23 \mathrm{ng} . \mathrm{m}^{-3}$ for $\mathrm{HBr}$, and 31.8 and $10.5 \mathrm{ng} . \mathrm{m}^{-3}$ for $\mathrm{Cl}^{-}$and $\mathrm{Br}^{-}$. Both aerosol deposition and the scavenging of $\mathrm{HCl}$ and $\mathrm{HBr}$ may have contributed to the increases in snow concentrations. Judging from the mass of snow present on the ground before and after the wind storm, sublimation by wind transport cannot explain the increase. In any case, this wind storm proves that large amounts of $\mathrm{Cl}^{-}$and $\mathrm{Br}^{-}$can rapidly be deposited to snow by wind. Enrichment by windpack crystals can be safely ruled out, as the concentrations there were lower than in both February layers, and $\mathrm{Br}^{-}$levels in particular were undetectable. Finally, while $\left(\mathrm{Cl}^{-}+\mathrm{HCl}\right) /\left(\mathrm{Br}^{-}+\mathrm{HBr}\right)$ in the atmosphere was 8.8 on a molar basis, the wind-blown snow took up about $50 \mu \mathrm{M}_{\text {of }} \mathrm{Cl}^{-}$and only about $0.3 \mu \mathrm{M}$ of $\mathrm{Br}^{-}$, indicating that $\mathrm{Cl}^{-}$was transferred to the snow much more efficiently than $\mathrm{Br}^{-}$, possibly because a greater fraction of chloride was in the aerosol form. A quantitative comparison of ion uptake with other wind storms will be done after the description of those observed at Ny-Ålesund.

\subsubsection{7 and 29 April 2001 layer, Ny-Ålesund}

The 27 April snow fall started around 7:00 until 11:00, while the air temperature (at $2.7 \mathrm{~m}$ height) was between -1 and 


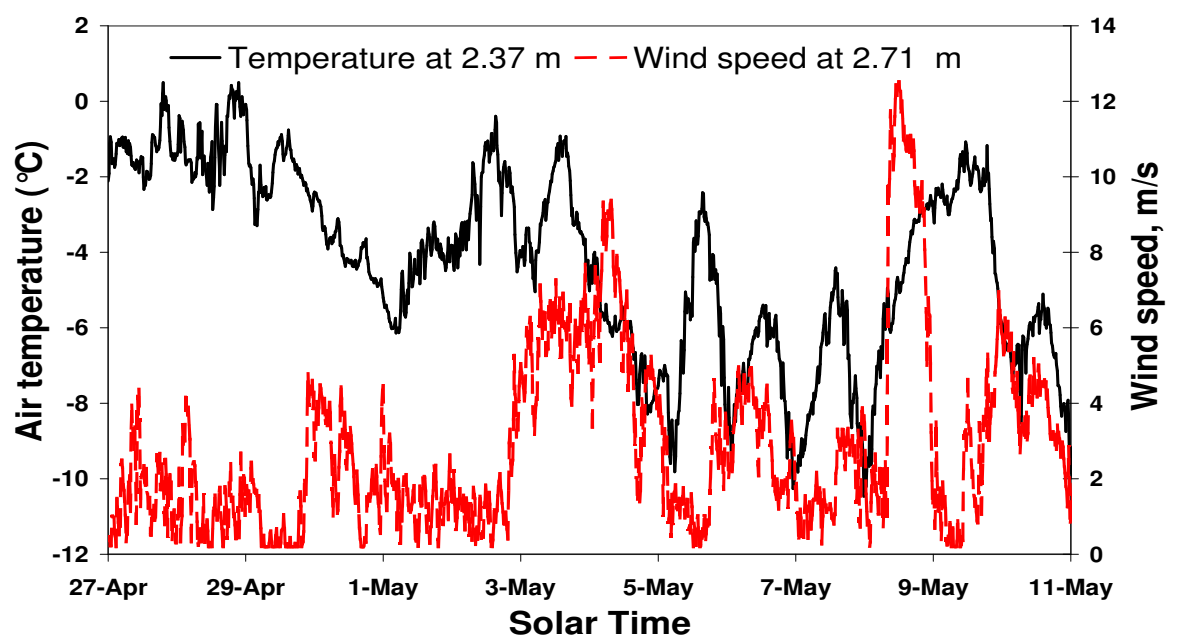

Fig. 7. Temperature and wind speed measured near Ny-Ålesund, within $50 \mathrm{~m}$ of our sampling site at the Amundsen mast, in spring 2001.

$-2^{\circ} \mathrm{C}$ (Fig. 7). It consisted of rimed dendritic crystals. Snow showers then occurred in the afternoon and evening, with snow crystals having various shapes: plates, dendritic crystals, and needles in the evening. The total thickness of the snowfall was about $3 \mathrm{~cm}$ (Fig. 8). The air temperature then rose to $0.5^{\circ} \mathrm{C}$ in the evening of both the 27th and the 28th under overcast conditions, initiating melting at the top of the layer. This produced a superficial melt-freeze crust about $5 \mathrm{~mm}$ thick that was still permeable and never resembled an ice layer. No percolation was observed in the underlying part of the layer. This snow layer was covered on 29 April by a new snowfall, $4.5 \mathrm{~cm}$ thick, made up of small irregular crystals that fell under air temperatures between 1 and $-3^{\circ} \mathrm{C}$, between 6:00 and 23:00. A wind crust progressively formed on the 29 April layer that reached a thickness of $1 \mathrm{~cm}$ on 4 May (Fig. 9). This new snowfall and the crust certainly hindered subsequent exchanges between the atmosphere and the 27 April layer.

At Ny-Ålesund, snow falls were very frequent, making conditions quite different from those at Alert. Solid precipitations were observed on 18, 20, 23 and 25 April, producing snow layers a few $\mathrm{cm}$ thick at the most. Also, while Alert is generally quite calm, there is always wind at Ny-Ålesund. As a result, some snow is frequently raised by wind, some layers are eroded and several different layers are exposed. A newly deposited layer can thus easily be contaminated by wind-raised snow, originating from different layers of potentially very different chemical composition. The snow surface is very irregular, with sastrugi about 5 to $20 \mathrm{~cm}$ high, of wavelength between 2 and $10 \mathrm{~m}$, that produce irregular wind pumping and therefore variable dry deposition of atmospheric species, whose snow concentrations are bound to be spatially very variable. The result of these conditions is that snow composition was found to be spatially heterogeneous, and triplicate samples often showed a large variability. The analytical procedure was essentially the same as at Alert, and thus cannot be the cause of the moderate to poor analytical reproducibility. We attempted to minimize the effect of those spatial variations by taking triplicate samples as close as possible to each other, and by doing subsequent sampling close to previous ones.

The 29 April snow layer was sampled at two levels: at the very surface (top $1 \mathrm{~cm}$ ) and about $3 \mathrm{~cm}$ below the surface. Figure 8 shows that initially, the 29 April snowfall was very poor in $\mathrm{Cl}^{-}: 0.5 \mu \mathrm{M}$ for the snow sampled at 13:00, when accumulation was about $2 \mathrm{~cm}$. Precipitating snow was also sampled at 18:30, when accumulation was about $4 \mathrm{~cm}$, and had a very low $\mathrm{Cl}^{-}$content: $1.9 \mu \mathrm{M}$. Subsequently, the $\mathrm{Cl}^{-}$ content of the middle part of the layer remained essentially stable around $2 \mu \mathrm{M}$, with one exception on 29 April when contamination by the underlying layer may have taken place, as suggested by the large standard deviation. On the contrary, the $\mathrm{Cl}^{-}$content of the top part of the layer, which was developing a wind crust, increased to $70 \mu \mathrm{M}$ on 30 April and remained stable around that concentration.

On 30 April, wind was moderate, between 3 and $4.5 \mathrm{~m} / \mathrm{s}$ for a large fraction of the day, and did not raise snow. According to the aerosol measurements of Teinilä et al. (2003), the $\mathrm{Cl}^{-}$atmospheric concentration was $276 \mathrm{ng} . \mathrm{m}^{-3}$, and the $\mathrm{Cl}^{-}$concentration increased rapidly to $70 \mu \mathrm{M}$ in the top sublayer, suggesting that dry deposition by wind-pumping was operative. After that windy spell, conditions were calm, with wind speed staying essentially below $2 \mathrm{~m} / \mathrm{s}$ until the last sampling on 2 May. The stability of the ionic concentrations in the top crust can be due to the low wind speed, or may also be attributed to the formation of the wind crust, with a much reduced permeability. The $\mathrm{Cl}^{-} / \mathrm{Na}^{+}$ratio stayed stable in the top part, around 1.0 with error bars around 0.3 . For the middle sublayers, error bars were around 1 or greater, and data are not meaningful. We then suggest that the increase in $\mathrm{Cl}^{-}$ in the top sublayer is due to the deposition of sea salt moderately depleted in $\mathrm{Cl}^{-}$, probably by acidification by sulphate, 


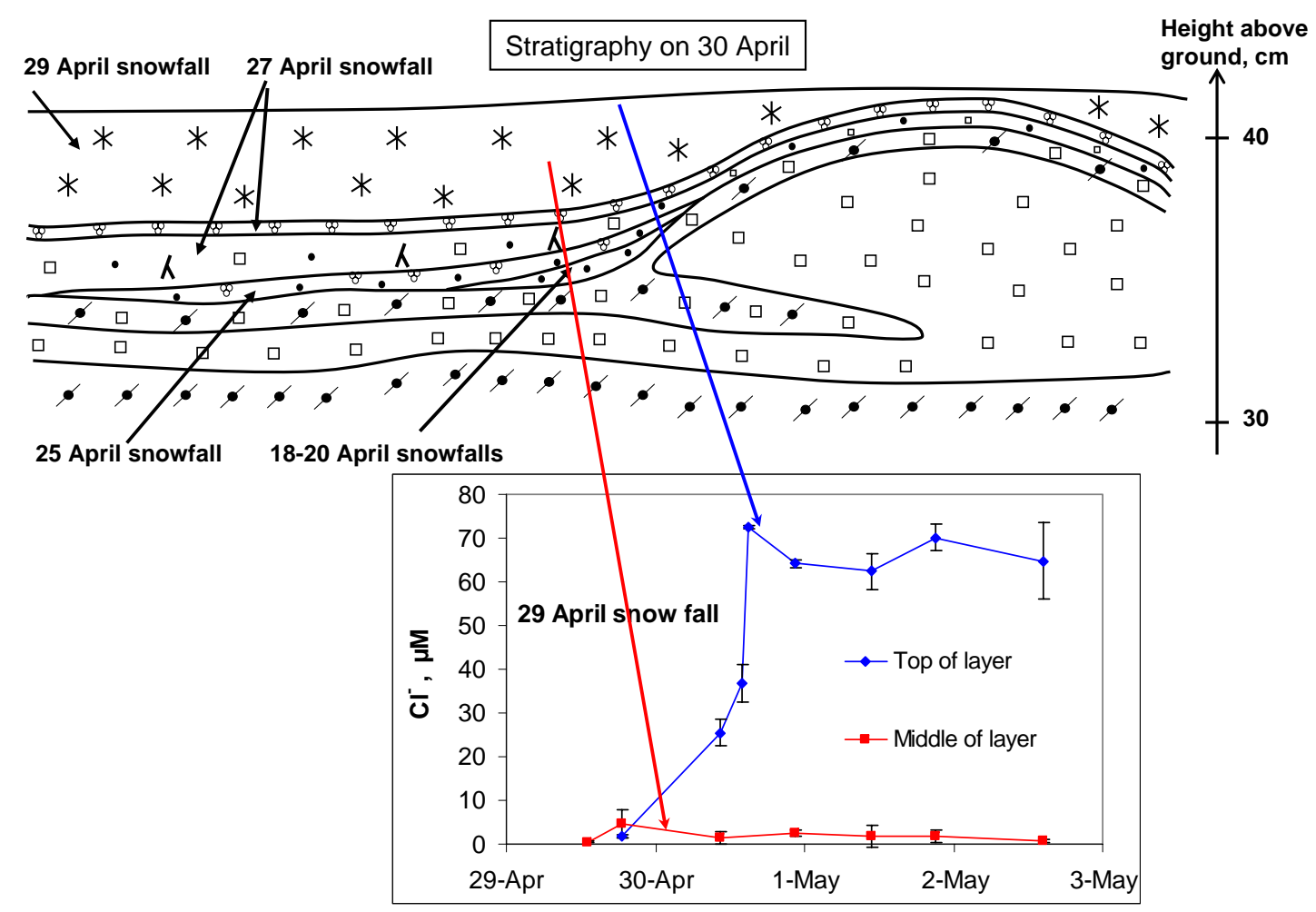

Fig. 8. Stratigraphy of the Ny-Ålesund snowpack on 30 April 2001, and time series of the $\mathrm{Cl}^{-}$concentration in two levels of the 29 April layer.

as suggested by the $\mathrm{SO}_{4}^{2-}$ content, around $7 \mu \mathrm{M}$, with no detectable deposition of $\mathrm{HCl}$.

The 27 April layers offer another excellent opportunity to evaluate the effect of dry deposition due to wind pumping. The storm of 8 May lasted $15 \mathrm{~h}$ (Fig. 7) with wind speeds reaching $12.5 \mathrm{~m} / \mathrm{s}$ that produced a strong erosion of the snow pack. Again according to Teinilä et al. (2003), the $\mathrm{Cl}^{-}$atmospheric concentration was $649 \mathrm{ng} \mathrm{m}^{-3}$. The top layer was the wind crust of the 29 April layer, that was partly eroded (Fig. 9). The unprotected soft snow from the 29 April layer became also quickly eroded, thus exposing the 27 April melt/freeze crust in many places, but not everywhere. Figure 9 shows that before the storm, the $\mathrm{Cl}^{-}$concentration of the 27 April crust remained essentially constant, around $40 \mu \mathrm{M}$, while its $\mathrm{Na}^{+}$content was around $35 \mu \mathrm{M}$. On 8 May at 23:00, the 27 April crust was sampled, both in exposed parts and in parts where it was still sheltered by the 29 April layer. Figure 9 clearly shows that the ion concentrations of the unexposed portion were not affected by the wind storm. On the contrary, the exposed portion saw its chloride content jump to $450 \mu \mathrm{M}$.

Analyses show that ionic ratios involving $\mathrm{Cl}^{-}, \mathrm{Br}^{-}, \mathrm{Na}^{+}$, $\mathrm{K}^{+}$, and $\mathrm{Mg}^{2+}$ are close to the sea water values, both in the exposed and sheltered parts. We thus conclude from this case study that (i) the $\mathrm{Cl}^{-}$and $\mathrm{Na}^{+}$in the 27 April melt/freeze crust were probably unfractionated sea salt, and not scav- enged $\mathrm{HCl}$. Likewise, after exposure on $8 \mathrm{May}^{-\mathrm{Cl}^{-}}$and $\mathrm{Na}^{+}$were again present as sea salt. (ii) Dry deposition, enhanced by wind pumping, can deposit enormous quantities of sea salt onto surface snow in just $15 \mathrm{~h}$. (iii) A few $\mathrm{cm}$ of snow are sufficient to shield underlying layers from sea salt deposition by wind pumping, at least with the surface snow structure that was observed. The depth of penetration of wind-pumped sea salt into snow then appears to be here only about $2 \mathrm{~cm}$. A similar depth can be derived from our study of the 29 April snow layer. Of course, we realize that this may vary with the physical properties of snow, and in particular with its permeability (Albert and Schultz, 2002).

\section{Conclusions}

The objective of this paper was to test the contribution of upward migration from the sea ice and deposition by wind to the ionic content of snow on sea ice. Wolff et al. (2003) and Rankin et al. (2002) hypothesized from Antarctic observations that wind-deposited ions may come essentially from frost flowers.

We observed that upward migration affects the snowpack up to at least $17 \mathrm{~cm}$ from the ice surface, where a $\mathrm{Cl}^{-}$concentration of $300 \mu \mathrm{M}$ was observed. Migration at Alert took place without detectable fractionation, suggesting that this process took place in the fall, when snowpack temperatures 


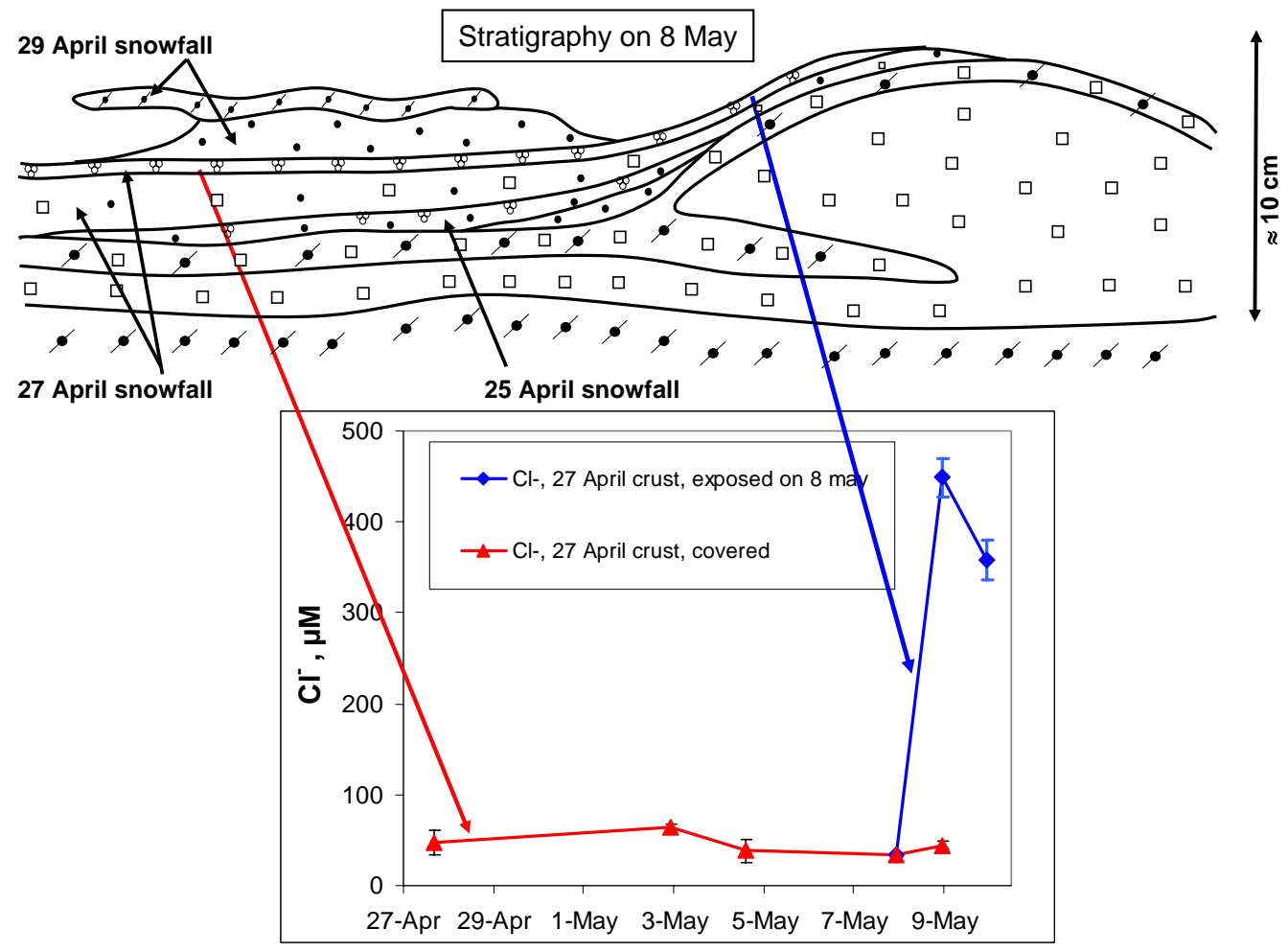

Fig. 9. Stratigraphy of the Ny-Ålesund snowpack on 8 May 2001, and time series of the $\mathrm{Cl}^{-}$concentration in melt/freeze crust of the 27 April layer. On 8 May, a windstorm eroded the overlying 29 April layer, partially exposing the crust. The $\mathrm{Cl}^{-}$concentration of the exposed crust is also shown starting on 8 May.

were above $-8^{\circ} \mathrm{C}$. Snow thickness on sea ice near Alert is very variable, between 0 and $50 \mathrm{~cm}$ (Domine et al., 2002). Eicken et al. (1994) observed variable snow thickness on the Weddell sea (Antarctica), with maximal frequencies around $5-25 \mathrm{~cm}$. Migration of ions from sea ice then indeed has the potential to affect a significant fraction of the surface snow layers on sea ice. The sea salt reaching the surface of the snowpack can then be transported by wind and scattered over the entire marine snowpack, where it then may be involved in chemical reactions affecting the atmosphere.

We could never come to the conclusion that most of the ions in surface snow came from upward migration from sea ice. This is in part because our selection of sampling sites was biased towards thicker snow banks, subjectively viewed as more interesting. Furthermore, dry deposition of $\mathrm{SO}_{4}^{2-}$ and $\mathrm{Ca}^{2+}$ onto surface layers can rapidly obscure any sea salt chemical signature and make the detection of upward migration in surface layers difficult. More case studies are needed, and we suggest that time series of vertical profiles on sea ice, over several weeks to months, would shed additional light on the actual impact of upward migration on surface snow composition.

The impact of wind deposition on snow composition was tested on land, to avoid interference from sea ice. We conclude that wind can rapidly increase ionic concentrations in snow, especially if the snow becomes airborne. Wind deposition was observed to lead to $\mathrm{Cl}^{-}$concentrations of $450 \mu \mathrm{M}$ at Ny-Ålesund, similar to those produced by upward migration on sea ice, $17 \mathrm{~cm}$ up the snow. This process was found to affect only the top $2 \mathrm{~cm}$ of the snowpack, but wind crusts or melt/freeze crusts were always present, and this may have limited the depth of penetration of wind-borne aerosols. In the Ny-Ålesund case, the deposited ions had clearly a sea salt signature without fractionation. Considering that the wind was coming from ice-free areas, this sea salt was certainly produced by sea spray, which can then significantly contribute to the sea salt content of snow. The highest $\left[\mathrm{Br}^{-}\right]$that we measured, $0.62 \mu \mathrm{M}$ in the wind-exposed 27 April layer at $\mathrm{Ny}$-Ålesund, was also caused by sea spray.

We now attempt a comparison between upward migration and frost flowers as possible sources of sea salt to the atmosphere. Based on Fig. 2, we assume that the marine snowpack has a mean $\left[\mathrm{Na}^{+}\right]$of $230 \mu \mathrm{M}$ over a depth of $20 \mathrm{~cm}$, with a mean density of 0.3 , and that such a snowpack covers $99 \%$ of the sea ice. We then assume that frost flowers have a mean $\left[\mathrm{Na}^{+}\right]$of $1.4 \mathrm{M}$, are $1 \mathrm{~cm}$ thick and have a mean density of 0.01 , and cover $1 \%$ of the sea ice. Even though some of these numbers could be debated, we find that the marine snowpack contains about 10 times more $\mathrm{Na}^{+}$than the frost flowers. Considering the approximations made, and the 
fact that the average $\left[\mathrm{Na}^{+}\right]$of the snow is not well known, both the marine snowpack and frost flowers appear to deserve consideration as sources of sea salt. The scatterring of frost flowers by wind is easy, but snowpack erosion can also be fairly efficient on sea ice, as we have observed that several $\mathrm{cm}$ of windpack could be eroded in a day. The recent modeling results of Kaleschke et al. (2004) may suggest that frost flowers are more efficient to trigger ODEs, possibly because they may be locally a more intense source of halogens to the atmosphere that marine snow. But we believe that the understanding of halogen exchange between the ocean and the atmosphere in Polar Regions requires the consideration of not only frost flowers, but also of upward migration from sea ice, and of transport from the open sea.

Our data from Alert and the northern Arctic Ocean also suggest that ozone depletion chemistry can significantly enhance the $\mathrm{Br}^{-}$content of snow. This suggests a mechanism to transport $\mathrm{Br}^{-}$over continents, and propagate bromidedriven ozone destruction over land.

Acknowledgements. This work was funded by the French Polar Institute (IPEV) through the MICHARC and POANA programs to FD, and by the European Commission through the NICE program to HJB. Field assistance by A. Gallant and campaign coordination by J. Bottenheim at Alert are gratefully acknowledged. FD thanks J. Morison (University of Washington) for offering transport to the Northern Arctic Ocean site. A. Felici, L. Ammiraglia and E. Colaiacomo (CNR-IIA) assisted with sampling and IC analyses at Ny-Ålesund. We thank K. Teinilä (Finnish Meteorological Service) for detailed aerosol data and T. Giorgiadis (CNR-IBIMET) for detailed meteorological data prior to publication. Stimulating discussions with W. R. Simpson and insightful comments on the paper by H. Eicken (both at GI-University of Alaska Fairbanks) are gratefully acknowledged. Anonymous reviewers also provided valuable comments.

Edited by: W. T. Sturges

\section{References}

Albert, M. R. and, Shultz, E.: Snow and firn properties and transport processes at Summit, Greenland, Atmos. Environ., 36, 27892797, 2002.

Allegrini, I., Ianniello, A., Montagnoli, M., Sparapani, R., and Mazzioti Gomez de Teran, C.: Carbon coated annular denuders and ion chromatography chromatographic measurements for the measurement determination of nitrogen nitrogen-containing species $\left(\mathrm{NO}_{2}\right.$ and $\left.\mathrm{NO}_{\mathrm{y}}\right)$ in remote atmospheres, J. Chromatogr. A, 846, 265-268, 1999.

Barrie, L. A., Bottenheim, J. W., Schnell, P. J., Crutzen, P. J., and Rasmussen, R. A.: Ozone destruction and photochemical reactions at polar sunrise in the lower Arctic atmosphere, Nature, 334, 138-141, 1988.

Beine, H. J., Dominé, F., Ianniello, A., Nardino, M., Allegrini, I., Teinilä, K., Hillamo, R.: Fluxes of Nitrates Between Snow Surfaces and the Atmosphere in the European High Arctic, Atmos. Chem. Phys., 3, 335-346, 2003,

SRef-ID: 1680-7324/acp/2003-3-335.
Bottenheim, J. W., Fuentes, J. D., Tarasick, D. W., and Anlauf, K. G.: Ozone in the Arctic lower troposphere during winter and spring 2000 (ALERT2000), Atmos. Environ., 36, 2535-2544, 2002a.

Bottenheim, J. W., Dibb, J. E., Honrath, R. E, and Shepson, P. B.: An introduction to the ALERT 2000 and SUMMIT 2000 Arctic research studies, Atmos. Environ., 36, 2467-2469, 2002b.

Buat-Ménard, P., Morelli, J., and Chesselet, R.: Water-soluble elements in atmospheric particulate matter over tropical and equatorial atlantic, J. Rech. Atmos., 8, 661-673, 1974.

Colbeck, S. C.: An overview of seasonal snow metamorphism, Rev. Geophys. Space Phys., 20, 45-61, 1982.

Colbeck, S., Akitaya, E., Armstong, R., Gubler, H., Lafeuille, J., Lied, K., McClung, D., and Morris, E.: The International Classification for Seasonal Snow on the Ground, ICSI, IGS, 1990.

Dominé, F. and Shepson, P. B.: Air-snow interactions and atmospheric chemistry, Science, 297, 1506-1510, 2002.

Dominé, F., Cabanes, A., and Legagneux, L.: Structure, microphysics, and surface area of the Arctic snowpack near Alert during ALERT 2000, Atmos. Environ., 36, 2753-2765, 2002.

Eicken, H., Lange, M. A., Hubberten, H. W., and Wadhams, P.: Characteristics and distribution patterns of snow and meteoric ice in the Weddell sea and their contribution to the mass balance of sea ice, Ann. Geophys., 13, 80-93, 1994.

Eicken, H., Krouse, H. R., Kadko, D., and Perovitch, D. K.: Tracer studies of pathways and rates of meltwater transport through Arctic summer sea ice, J. Geophys. Res., 107, 8046, doi:10.1029/2000JC000583, 2002.

Fan, S.-M. and Jacob, D. J.: Surface ozone depletion in Arctic spring sustained by bromine reactions on aerosols, Nature, 359, 522-524, 1992.

Foster, K., Plastridge, R., Bottenheim, J., Shepson, P., FinlaysonPitts, B., and Spicer, C. W.: First Tropospheric Measurements of $\mathrm{Br}_{2}$ and $\mathrm{BrCl}$ and Their Role in Surface Ozone Destruction at Polar Sunrise, Science, 291, 471-474, 2001.

Garrity, C.: Characterization of snow on floating ice and case studies of brightness temperature changes during the onset of melt, in: Microwave remote sensing of sea ice, edited by: Carsey, F. D., Geophysical monograph 68, American Geophysical Union, 313-328, 1992.

Holland, H. D.: The chemistry of the atmosphere and oceans, Chap. 5, Wiley-Intersciences, New York, 1978.

Ianniello, A., Beine, H. J., Sparapani, R., Di Bari, F., Allegrini, I., Fuentes, J.: Denuder measurements of gas and aerosol species above Arctic snow surfaces at Alert 2000, Atmos. Environ., 36, 5299-5309, 2002.

Kaleschke, L., Richter, A., Burrows, J., Afe, O., Heygster, G., Notholt, J., Rankin, A. M., Roscoe, H. K., Hollwedel, J., Wagner, T., and Jacobi, H.-W.: Frost flowers on sea ice as a source of sea salt and their influence on tropospheric halogen chemistry, Geophys. Res. Lett., 31, L16114, 2004.

Legagneux, L., Cabanes, A., and Dominé, F.: Measurement of the Specific Surface Area of 176 Snow Samples Using Methane Adsorption at 77 K, J. Geophys. Res., 107 (D17), 4335, doi:10.1029/2001JD001016, 2002.

Legrand, M. R. and Delmas, R. J.: Formation of $\mathrm{HCl}$ in the Antarctic atmosphere, J. Geophys. Res., 93, 7153-7168, 1988.

Martin, S., Drucker, R., and Ford, M.: A laboratory study of frost flower growth on the surface of young sea ice, J. Geophys. Res., 
100, 7027-7036, 1995.

Massom, R. A., Eicken, H., Haas, C., Jeffries, M. O., Drinkwater, M. R., Sturm, M., Worby, A. P., Wu, X., Lytle, V. I., Ushio, S., Morris, K., Reid, P. A., Warren, S., and Allison, I.: Snow on Antarctic sea ice, Rev. Geophys., 39 (3), 413-445, 2001.

Perovich, D. K. and Richter-Menge, J. A.: Surface characteristics of lead ice, J. Geophys. Res., 99, 16341-16350, 1994.

Perrino, C., Ramirez, D., and Allegrini, I.: Monitoring acidic air pollutants near Rome by means of diffusion lines: development of a specific quality control procedure, Atmos. Environ., 35, 331-341, 2001.

Rankin, A. M., Auld, V., and Wolff, E. W.: Frost flowers as a source of fractionated sea salt aerosol in the polar regions, Geophys. Res. Lett., 27, 3469-3472, 2000.

Rankin, A. M., Wolff, E. W., and Martin, S.: Frost flowers: implications for tropospheric chemistry and ice core interpretation, J. Geophys. Res., 107, 4683, doi:10.1029/2002JD002492, 2002.

Solberg, S., Schmidtbauer, A., Semb, A., and Stordal, F.: Boundary-layer ozone depletion as seen in the Norwegian Arctic in spring, J. Atmos. Chem., 23, 301-332, 1996.
Tang, T. and Mc Connell, J. C.: Autocatalytic release of bromine from arctic snow pack during polar sunrise, Geophys. Res. Lett., 23, 2633-2636, 1996.

Tarasick, D. W. and Bottenheim, J. W.: Surface ozone depletion episodes in the Arctic and Antarctic from historical ozonesonde records, Atmos. Chem. Phys., 2, 197-205, 2002,

SRef-ID: 1680-7324/acp/2002-2-197.

Teinalä, K., Hillamo, R., Kerminen, V.-M., and Beine, H. J.: Chemistry and modal parameters of major ionic aerosol components during the NICE campaign at two altitudes, Atmos. Environ., 38, 1481-1490, 2004.

Toom-Sauntry, D. and Barrie, L. A.: Chemical Composition of Snowfall in the High Arctic 1990-1994, Atmos. Environ., 36, 2683-2693, 2002

Wagenbach, D., Ducroz, F., Mulvaney, R., Keck, L., Minikin, A. Legrand, M., Hall, J. S., and Wolff, E. W.: Sea-salt aerosol in coastal Antarctic regions, J. Geophys. Res., 103, 10 961-10974, 1998.

Wolff, E. W., Rankin, A. M., and Röthlisberger, R.: An ice core indicator of Antarctic sea ice production?, Geophys. Res. Lett., 30, 2158, doi:10.1029/2003GL018454, 2003. 